\title{
Clinical Residents' Perception of Clinical Librarian Services in Iranian Teaching Hospitals
}

\author{
Niloofar Mohaghegh \\ Medical Library and Information Sciences, \\ School of Health Management and Information Sciences, \\ Iran University of Medical Sciences, Iran \\ mohaghegh.n@iums.ac.ir \\ Afsaneh Dehnad \\ English Language Department, School of Health Management and Information Sciences, \\ Iran University of Medical Sciences, Iran \\ dehnad.a@iums.ac.ir \\ Maryam Zarghani (corresponding author), \\ School of Health Management and Information Sciences, \\ Iran University of Medical Sciences, Iran \\ zarghani.m@iums.ac.ir \\ Mohammadhiwa Abdekhoda \\ Department of Medical Library and Information Sciences, \\ School of Health Management and Medical Informatics, \\ Tabriz University of Medical Sciences, Iran \\ hiwaabdekhoda@gmail.com

\section{Shirin Mohamadzadeh} \\ English Language Department, \\ Alzahra University, Iran \\ shirinmzadeh@gmail.com
}

\begin{abstract}
Background. Clinical librarians have specialized search skills to search medical databases to provide clinicians with medical research information needed for evidence-based clinical decision making. However, the importance of cooperation between librarians and healthcare teams does not seem to be well-recognized by clinicians.

Objectives. The present study aimed to shed light on the importance of the cooperation between medical librarians and healthcare teams by probing clinicians' viewpoints and their familiarity with librarians' service.


Methods. The population comprised 890 clinical residents at teaching hospitals of the Iran University of Medical Sciences in 2016-2017. A questionnaire survey was carried out with 260 respondents.

Results. A majority of the clinical residents did not use services provided by clinical librarians. However, some used the following services: changing treatment behavior based on evidence-based information (3.4\%), obtaining evidence-based information (5.0\%), accessing clinical guidelines $(12.7 \%)$, and getting familiar with recent scientific discoveries $(6.7 \%)$. The residents approved of the presence of librarians who have most of the professional skills necessary for cooperation.

Contributions. The presence of clinical librarians with appropriate skills in the healthcare team can help resolve some problems clinical residents face while searching.

\section{INTRODUCTION}

Attainment of up-to-date information and knowledge is of utmost importance in medical services. It is well known that the healthcare team often faces unpredictable problems and uncertainty in decision making in the clinical setting. In these cases, timely access to information and knowledge from medical resources prevents mistakes and promotes medical services (Abdekhoda \& Dibaj, 2011; Valinejadi, Pasiar, \& Shokraneh, 2008). Physicians and other members of the healthcare team often face issues such as limited skills in searching and retrieving information and have time constraints for this purpose (Hashemian, Janatikia, \& Hashemian, 2010). Therefore, the presence of an information specialist with information seeking skills in specialized domains can play a significant role in meeting the healthcare team's need for information and in improving their decision making capability, thus enhancing the quality of clinical services. An information specialist working in the field of medicine is referred to as a clinical librarian.

Clinical librarians attend different hospital wards at physicians' working hours, participate in daily and weekly sessions of the clinical team, directly learn about their information related needs, search medical resources, and provide the healthcare team with relevant information retrieved from reliable sources. As a result, the clinical team is able to make correct decisions using up-to-date information which leads to the promotion of healthcare services (Shali \& Bagheri, 2008).

With the emergence of Evidence-Based Medicine (EBM), medical librarians have adopted the role of clinical librarians who are responsible for searching and finding answers, based on peer-reviewed literature, to the questions of clinicians. The success of librarians in taking this role and making use of their skills in searching, retrieving and evaluating evidencebased information provide important support to clinicians in making clinical decisions based on the best available evidence. Clinical librarians are responsible for posing questions (Shokraneh, 2015) based on Patient, Intervention, Comparison, Outcome (PICO) and searching for evidencebased information, both of which are emphasized in the first and second steps of the five-step process of answering clinical questions in the EBM process. This is possibly justified by clinicians' lack of time to attend EBM related training programs (Valinejadi, Pasiar, \& Shokraneh, 2008). 
The first step of EBM is asking questions by clinicians whose questions may be ambiguous or lack enough details, thus preventing a good search. This problem can be solved by the interaction between clinicians and librarians. The second step of EBM is formulating the question in terms of PICO which requires knowledge of the basic elements of a question. The third step of EBM is searching for and finding evidence, which is the main job of librarians. The fourth step is the critical appraisal of evidence for which understanding of medical research based on EBM standards is required. It is worth mentioning that in many studies, the fourth step and fifth step, that is, acting on the evidence and evaluating its outcome (performed by physicians, not clinical librarians) are not discussed (Shokraneh, Eskrochi, Ghafoori, \& Ghohari, 2010).

Although clinicians do not make the best use of clinical librarians' services, the cooperation between them is not a new experience. For example, a review of literature shows that Literature Attached to Charts (LATCH), which is the first program involving librarians in healthcare, was initiated in 1967 in Washington Hospital Center in Washington DC, USA (Buchalter, 2013).

To demonstrate the role and status of librarians as an effective member of the healthcare team, it is vital to provide clinical librarian services in healthcare centers. Typically, there are seven skills essential for clinical librarians (apart from individual and personal skills), as follows:

- Having medical knowledge

- Familiarity with important medical information resources for every specialty

- Mastery of search strategies

- Familiarity with EBM and different types of clinical questions

- Knowledge of clinical decision-making methods

- Mastery of the English language

- Mastery of computer and Internet skills (Shokraneh, 2015).

A graduate medical librarian with these seven skills can work as a clinical librarian (Shokraneh, 2015). In addition to these skills, other factors such as continuous learning, familiarity with changes in clinical care, and subject knowledge of the medical field contribute to the success of a clinical librarian (Buchalter, 2013).

One of the missions of clinical librarianship is training clinical librarians to cooperate with and assist the healthcare team in hospitals and healthcare centers. Clinical librarians learn medical concepts with academic education, and become familiar with major topics of clinical care. A forgotten goal, however, is the importance of cooperation with or employment of clinical librarians in clinical settings proving to be a missing link.

The present study aimed to delineate the importance of this presence based on the level of familiarity of medical residents with the noted cooperation with clinical librarians. Specifically, the present study assessed the familiarity of clinicians with the services provided by clinical librarians in hospitals affiliated with the Iran University of Medical Sciences, Tehran, Iran, in 2016. The following objectives were set forth:

- Investigating the level of familiarity of clinical residents with medical databases

- Assessing residents' viewpoints about the effects of clinical librarian services on clinical services provided

- Exploring the perspective of residents regarding the presence of clinical librarians in the healthcare team. 


\section{METHOD}

The present descriptive study was designed in two phases and employed a researcher-constructed questionnaire, with relevant statements that the respondent was asked to score on a five-point Likert-like scale. First, the questionnaire was designed on the basis of a library search and researchers' personal experiences. It was then sent to 15 library and information science experts to confirm its surface validity. From among these, 10 responded, and the final edition was approved by them. In the next step, 30 copies of the questionnaire were distributed among residents at Firouzgar Hospital as part of the study population to check its reliability. Data were analyzed using SPSS 18 statistical software, and a Cronbach's alpha of 0.87 confirmed the reliability of the questionnaire. After the final approval, the research instrument was distributed among residents in the hospitals under study.

The research population comprised all clinical residents at teaching hospitals affiliated with the Iran University of Medical Sciences in 2016-2017, estimated at 890. The appropriate sample size was determined using Cochran's formula together with Morgan's table, because the population variance was not available. Accordingly, the sample size was determined as 260 from the population of 890. Data were analyzed using SPSS 18 to derive descriptive statistics. Furthermore, the normality of data was checked using the Kolmogorov-Smirnov test, and then the Mann-Whitney U was employed to determine whether two independent samples were selected from the same population.

\section{RESULTS}

Of the 260 respondents, 148 were male and 112, female. Of the 15 teaching hospitals affiliated with the Iran University of Medical Sciences participating in the study, the highest number of respondents (28) worked at Firouzgar Hospital and were from 27 specialties. The majority of the returned questionnaires were completed by residents of pediatrics (29), gynecology (21), and internal medicine (23). Also, the majority of residents (99) had been engaged in the residency program for about a year in these hospitals.

Based on Table 1, residents were most familiar with PubMed (25.4\%) and up-to-date (23.8\%) and least familiar with BMJ Clinical Evidence (3.8\%). The result of the Mann-Whitney $\mathrm{U}$ test indicates no significant difference between men and women in terms of familiarity with databases $(\mathrm{p}=0.95)$.

Table 2 indicates that, the majority of residents reported very little use of clinical librarian services. Residents, however, reported that they used the following services very much: changing the treatment methods based on evidence-based information (3.4\%), assisting in obtaining evidence-based information (5\%), intending to access clinical guidelines (12.7\%), and the most recent scientific discoveries in specialized fields (6.7\%). No difference was observed between females and males in this regard based on the Mann-Whitney $U$ test $(p=0.65)$.

As Table 3 shows, the majority of residents reported that the presence of clinical librarians was necessary by choosing high (36.5\%) and very high (28.2\%), whereas only $9.2 \%$ stated that the presence of librarians was not quite necessary. 
Table 1. Frequency and percentage of residents familiar with databases

\begin{tabular}{lllllll}
\hline Database & Very little & A little & Average & High & Very high & Total \\
\hline Up-to-date & $4.2 \%$ & $7.3 \%$ & $31.2 \%$ & $33.5 \%$ & $23.8 \%$ & $100 \%$ \\
& $(11)^{*}$ & $(19)$ & $(81)$ & $(87)$ & $(62)$ & $(260)$ \\
Clinical key & $12.3 \%$ & $9.6 \%$ & $31.9 \%$ & $32.7 \%$ & $13.5 \%$ & $100 \%$ \\
& $(32)$ & $(25)$ & $(83)$ & $(85)$ & $(35)$ & $(260)$ \\
Cochrane & $38.8 \%$ & $16.5 \%$ & $25.4 \%$ & $13.5 \%$ & $5.8 \%$ & $100 \%$ \\
& $(101)$ & $(43)$ & $(66)$ & $(35)$ & $(15)$ & $(260)$ \\
Ovid-Medline & $35 \%$ & $15.7 \%$ & $21.9 \%$ & $21.2 \%$ & $6.2 \%$ & $100 \%$ \\
& $(91)$ & $(41)$ & $(57)$ & $(55)$ & $(16)$ & $(260)$ \\
PubMed & $14.2 \%$ & $11.5 \%$ & $18.1 \%$ & $30.8 \%$ & $25.4 \%$ & $100 \%$ \\
& $(37)$ & $(30)$ & $(47)$ & $(80)$ & $(66)$ & $(260)$ \\
BMJ clinical & $41.2 \%$ & $18.5 \%$ & $24.2 \%$ & $12.3 \%$ & $3.8 \%$ & $100 \%$ \\
evidence & $(107)$ & $(48)$ & $(63)$ & $(32)$ & $(10)$ & $(260)$ \\
BMJ best practice & $48.5 \%$ & $18.8 \%$ & $16.6 \%$ & $11.6 \%$ & $4.5 \%$ & $100 \%$ \\
& $(126)$ & $(49)$ & $(43)$ & $(30)$ & $(12)$ & $(260)$ \\
\hline
\end{tabular}

Note: *Frequency

\section{DISCUSSION}

From Table 1, residents were least familiar with BMJ Clinical Evidence (3.8\%). The relatively low familiarity of the healthcare team with databases can easily be resolved with the cooperation of information specialists, that is, clinical librarians, as one of their major responsibilities is introducing resources to the healthcare team to meet their needs. Similarly, Eresuma and Lake (2016) stated that the healthcare team often faces problems in finding resources and checking the background of clinical activities for different reasons, including time constraints and limited information seeking skills, while evidence-based and valid information can be provided for the healthcare team in a short time by the assistance of skilled clinical librarians (Eresuma \& Lake, 2016).

According to Table 2, clinical librarian services in hospitals, and cooperation with the healthcare team have been reported as very little. This is mainly due to the lack of interaction between residents and librarians as well as residents' unfamiliarity with the skills and role of librarians in identifying sources of information and retrieval of accurate and relevant information. When asked about the effects of the presence of librarians in the healthcare teams, residents recounted the likelihood of the effects on changing treatment methods based on evidence-based information (3.4\%), assistance in obtaining evidence-based information (5\%), access to clinical guidelines (12.7\%), and familiarity with the most recent scientific discoveries in specialized fields (6.7\%). While the role of librarians can be much more prominent in searching and retrieving information, the large and increasing volume of information available today in printed and online forms further demonstrates one skill of librarians, that is, providing prompt access to valid sources.

Motamedi, AleTaha and Bahaadini (2014) conducted a study in Kerman University with opposite results. The results of their study revealed that $80 \%$ of answers provided by librarians to 
Table 2. Frequency and percentage of the purposes for which residents use clinical librarians' services

\begin{tabular}{lllllll}
\hline $\begin{array}{l}\text { Purposes for residents using } \\
\text { clinical librarians' services }\end{array}$ & $\begin{array}{l}\text { Very } \\
\text { little }\end{array}$ & A little & Average & Much & $\begin{array}{l}\text { Very } \\
\text { much }\end{array}$ & Total \\
\hline Assistance in differential diagnosis & $46.2 \%$ & $21.1 \%$ & $21.4 \%$ & $8.2 \%$ & $3.1 \%$ & $100 \%$ \\
& $(107) \%$ & $(58)$ & $(59)$ & $(25)$ & $(11)$ & $(260)$ \\
Changing the treatment behavior & $37.7 \%$ & $22.3 \%$ & $28.5 \%$ & $8.1 \%$ & $3.4 \%$ & $100 \%$ \\
based on evidence-based & $(98)$ & $(58)$ & $(74)$ & $(21)$ & $(9)$ & $(260)$ \\
information & & & & & & \\
Identification of normal or & $39.6 \%$ & $19.2 \%$ & $28.1 \%$ & $9.3 \%$ & $3.8 \%$ & $100 \%$ \\
abnormal treatment status & $(103)$ & $(50)$ & $(73)$ & $(24)$ & $(10)$ & $(260)$ \\
Assistance in obtaining evidence- & $34.6 \%$ & $23.4 \%$ & $26.2 \%$ & $10.8 \%$ & $5 \%$ & $100 \%$ \\
based information & $(90)$ & $(61)$ & $(67)$ & $(29)$ & $(13)$ & $(260)$ \\
Familiarity with the newest & $38.8 \%$ & $21.5 \%$ & $21.5 \%$ & $11.5 \%$ & $6.7 \%$ & $100 \%$ \\
scientific achievements in medicine & $(101)$ & $(56)$ & $(56)$ & $(30)$ & $(17)$ & $(260)$ \\
in general, and your specialty in & & & & & & \\
particular & & & & & & \\
Access to pharmaceutical & $36.2 \%$ & $15.8 \%$ & $25.3 \%$ & $15 \%$ & $7.7 \%$ & $100 \%$ \\
information & $(94)$ & $(41)$ & $(66)$ & $(39)$ & $(20)$ & $(260)$ \\
Access to clinical guidelines & $34.2 \%$ & $17.3 \%$ & $20.8 \%$ & $15 \%$ & $12.7 \%$ & $100 \%$ \\
& $(89)$ & $(45)$ & $(54)$ & $(39)$ & $(33)$ & $(260)$ \\
Learning about alternative & $40.8 \%$ & $21.2 \%$ & $19.5 \%$ & $10.8 \%$ & $7.7 \%$ & $100 \%$ \\
treatments & $(106)$ & $(55)$ & $(51)$ & $(28)$ & $(20)$ & $(260)$ \\
\hline
\end{tabular}

Note: *Frequency

Table 3. Frequency and percentage of residents reporting the need for the presence of clinical librarians in the healthcare team

\begin{tabular}{lllllll}
\hline & Very little & A little & Average & High & Very high & Total \\
\hline Percentage & $9.2 \%$ & $9.2 \%$ & $16.9 \%$ & $36.5 \%$ & $28.2 \%$ & $100 \%$ \\
(Frequency) & $(24)$ & $(24)$ & $(44)$ & $(95)$ & $(73)$ & $(260)$ \\
\hline
\end{tabular}

physicians in response to their questions were excellent and accurate, 10\% were good, and only 10\% were incorrect (Motamedi et al., 2014). Moreover, Brettle, Maden, and Payn (2010) examined four models of librarian services. All these models emphasized the positive role of clinical librarians in saving the time of healthcare workers and providing high-quality and valuable information. They also noticed the positive effect of clinical librarians on informed clinical decision making for diagnosis, choice of medication, and treatment. Brahmi and Kaplan (2017) also focused on the positive presence of librarians in the surgical team, noting the following services: education, research, use of novel information technologies for providing information services to the healthcare team using long distance communication networks (Brahmi \& Kaplan, 2017). 
Based on Table 3, the majority of clinical residents (36.5\% and $28.2 \%$ selecting high and very high respectively) are in favor of the presence of clinical librarians in the healthcare team. This is probably because specialists had become aware of the services of clinical librarians upon reading previous questions and, therefore, considered their presence in the team important. Motamedi et al. (2014) suggested that clinical librarians should improve their knowledge of the English language in order to obtain more accurate results from the search. Moreover, a better telecommunication infrastructure and higher Internet speed are required for the online searching of sources and sending them to physicians (Motamedi et al., 2014). According to Harrison and Beraquet (2009), the major activity performed by librarians is searching for information for physicians and, therefore, they must be engaged in healthcare-related activities (Harrison \& Beraquet, 2009). Ashrafirizi, Sharzadi and Soleimani (2016) considered the activities of medical librarians and information scientists as expanding beyond libraries. With numerous informationseeking skills, librarians can provide services such as teaching media literacy, information literacy, health literacy, health infometrics, health information science, and clinical services in various health-related domains, thereby assisting the healthcare team (Ashrafirizi et al., 2016). In addition, Steele and Tiffin (2014) considered the cooperation of clinical librarians with the healthcare team as effective and stated that clinical librarians can enhance the quality of personal care by teaching information-seeking skills. According to Esparza, Shi, McLarty, Comegys and Banks (2013), the cooperation between physicians and clinical librarians serves as a model for further studies and saves treatment time.

Table 4 lists the skills of clinical librarians in detail from the perspective of residents. The results show that the majority of residents consider the importance of these two skills as very much: familiarity with major medical databases in each specialty $(43.1 \%)$ and the ability to cooperate with the healthcare team (38.4\%). The importance of other skills was high according to residents who believed that, to cooperate with and be present in the healthcare team, librarians must have all the noted skills so that they can actively interact with the team. Each skill in Table 4 had over $50 \%$ of the respondents indicating much or very much. Hence, clinical librarians must have the majority of these skills in order to work in the healthcare team.

Roper (2015) noted that clinical managers and specialists know the important role of clinical librarians in healthcare teams and emphasize that this profession will prove a professional requirement in the future, and clinical librarians should be trained to cooperate with the healthcare team. Furthermore, Aitken, Powelson, Reaume and Ghali (2011) report that $88 \%$ of treatment plans developed by the healthcare team are altered as a result of skills taught by clinical librarians. The presence of clinical librarians has positive effects, leading to better clinical decision making by providing accurate information. Azadehtafreshi, Momenzadeh, Fayazbakhsh and Khodaei (2010) also concluded that most physicians and librarians consider it best to combine new information with clinical experience and patients' expectations. They cited the limited time available to physicians for diagnosis and comparing the it with new information. They enumerated the following as the major obstacles to the implementation of EBM: time constraint, lack of retrieval and evaluation skills, difficulty of working with patients as it is timeconsuming to explain matters to them, large volume of medical information, lack of access to some information, unavailability of valid information in many medical domains, and lack of investments by the government. Finally, Brettle et al. (2016) emphasized the positive role of clinical librarians in patient care, improvement of services, and treatment cost reduction through 
valid information which affects clinical decision making. They indicated that the presence of clinical librarians in the healthcare team will be essential in future.

Table 4. Frequency distribution of skills required for clinical librarians to be present in the healthcare team from the viewpoint of residents

\begin{tabular}{|c|c|c|c|c|c|c|}
\hline Skills & $\begin{array}{l}\text { Very } \\
\text { little }\end{array}$ & A little & Average & Much & $\begin{array}{l}\text { Very } \\
\text { much }\end{array}$ & Total \\
\hline $\begin{array}{l}\text { Sufficient information regarding } \\
\text { clinical services }\end{array}$ & $\begin{array}{l}5 \% \\
(13)\end{array}$ & $\begin{array}{l}7.3 \% \\
(19)\end{array}$ & $\begin{array}{l}23.1 \% \\
(60)\end{array}$ & $\begin{array}{l}28.8 \% \\
(75)\end{array}$ & $\begin{array}{l}35.8 \% \\
(93)\end{array}$ & $\begin{array}{l}100 \% \\
(260)\end{array}$ \\
\hline Mastery of network and technology & $\begin{array}{l}3.1 \% \\
(8)\end{array}$ & $\begin{array}{l}7.3 \% \\
(19)\end{array}$ & $\begin{array}{l}21.9 \% \\
(57)\end{array}$ & $\begin{array}{l}30 \% \\
(78)\end{array}$ & $\begin{array}{l}37.7 \% \\
(98)\end{array}$ & $\begin{array}{l}100 \% \\
(260)\end{array}$ \\
\hline $\begin{array}{l}\text { Ability to simultaneously cooperate } \\
\text { with the healthcare team }\end{array}$ & $\begin{array}{l}3.5 \% \\
(9)\end{array}$ & $\begin{array}{l}8.5 \% \\
(22)\end{array}$ & $\begin{array}{l}20 \% \\
(53)\end{array}$ & $\begin{array}{l}29.6 \% \\
(77)\end{array}$ & $\begin{array}{l}38.4 \% \\
(99)\end{array}$ & $\begin{array}{l}100 \% \\
(260)\end{array}$ \\
\hline $\begin{array}{l}\text { Reminding you of and providing } \\
\text { you with new medical findings }\end{array}$ & $\begin{array}{l}3.8 \% \\
(10)\end{array}$ & $\begin{array}{l}6.2 \% \\
(16)\end{array}$ & $\begin{array}{l}19.3 \% \\
(50)\end{array}$ & $\begin{array}{l}28.8 \% \\
(75)\end{array}$ & $\begin{array}{l}41.9 \% \\
(109)\end{array}$ & $\begin{array}{l}100 \% \\
(260)\end{array}$ \\
\hline $\begin{array}{l}\text { Scientific and information } \\
\text { counseling for healthcare teams }\end{array}$ & $\begin{array}{l}3.8 \% \\
(10)\end{array}$ & $\begin{array}{l}6.5 \% \\
(17)\end{array}$ & $\begin{array}{l}24.6 \% \\
(64)\end{array}$ & $\begin{array}{l}29.6 \% \\
(77)\end{array}$ & $\begin{array}{l}35.5 \% \\
(92)\end{array}$ & $\begin{array}{l}100 \% \\
(260)\end{array}$ \\
\hline $\begin{array}{l}\text { Providing medical information } \\
\text { through educational courses, } \\
\text { workshops, brochures, and } \\
\text { messaging systems }\end{array}$ & $\begin{array}{l}2.7 \% \\
\text { (7) }\end{array}$ & $\begin{array}{l}7.7 \% \\
(20)\end{array}$ & $\begin{array}{l}21.5 \% \\
(56)\end{array}$ & $\begin{array}{l}29.2 \% \\
(76)\end{array}$ & $\begin{array}{l}38.9 \% \\
(101)\end{array}$ & $\begin{array}{l}100 \% \\
(260)\end{array}$ \\
\hline $\begin{array}{l}\text { Full knowledge of medical, } \\
\text { therapeutic, and pharmaceutical } \\
\text { terms }\end{array}$ & $\begin{array}{l}2.7 \% \\
(7)\end{array}$ & $\begin{array}{l}6.2 \% \\
(16)\end{array}$ & $\begin{array}{l}28.8 \% \\
(75)\end{array}$ & $\begin{array}{l}28.8 \% \\
(75)\end{array}$ & $\begin{array}{l}33.5 \% \\
(87)\end{array}$ & $\begin{array}{l}100 \% \\
(260)\end{array}$ \\
\hline Continuous learning & $\begin{array}{l}2.7 \% \\
(7)\end{array}$ & $\begin{array}{l}10.4 \% \\
(27)\end{array}$ & $\begin{array}{l}23.8 \% \\
(62)\end{array}$ & $\begin{array}{l}28.5 \% \\
(74)\end{array}$ & $\begin{array}{l}34.6 \% \\
(90)\end{array}$ & $\begin{array}{l}100 \% \\
(260)\end{array}$ \\
\hline Having a teamwork spirit & $\begin{array}{l}3.1 \% \\
(8)\end{array}$ & $\begin{array}{l}6.2 \% \\
(16)\end{array}$ & $\begin{array}{l}25.4 \% \\
(66)\end{array}$ & $\begin{array}{l}28.5 \% \\
(74)\end{array}$ & $\begin{array}{l}36.8 \% \\
(96)\end{array}$ & $\begin{array}{l}100 \% \\
(260)\end{array}$ \\
\hline Strong interactional skills & $\begin{array}{l}1.9 \% \\
(6)\end{array}$ & $\begin{array}{l}8.5 \% \\
(22)\end{array}$ & $\begin{array}{l}20.8 \% \\
(54)\end{array}$ & $\begin{array}{l}30.9 \% \\
(80)\end{array}$ & $\begin{array}{l}37.9 \% \\
(98)\end{array}$ & $\begin{array}{l}100 \% \\
(260)\end{array}$ \\
\hline $\begin{array}{l}\text { Familiarity with important medical } \\
\text { information resources for every } \\
\text { specialty }\end{array}$ & $\begin{array}{l}3.8 \% \\
(10)\end{array}$ & $\begin{array}{l}7.7 \% \\
(20)\end{array}$ & $\begin{array}{l}19.2 \% \\
(50)\end{array}$ & $\begin{array}{l}26.2 \% \\
(68)\end{array}$ & $\begin{array}{l}43.1 \% \\
(112)\end{array}$ & $\begin{array}{l}100 \% \\
(260)\end{array}$ \\
\hline $\begin{array}{l}\text { Familiarity with EBM and different } \\
\text { types of clinical questions }\end{array}$ & $\begin{array}{l}3.5 \% \\
(9)\end{array}$ & $\begin{array}{l}6.5 \% \\
(17)\end{array}$ & $\begin{array}{l}27.3 \% \\
(71)\end{array}$ & $\begin{array}{l}29.6 \% \\
(77)\end{array}$ & $\begin{array}{l}33.1 \% \\
(86)\end{array}$ & $\begin{array}{l}100 \% \\
(260)\end{array}$ \\
\hline Mastery of the English language & $\begin{array}{l}3.1 \% \\
(8)\end{array}$ & $\begin{array}{l}10 \% \\
(26)\end{array}$ & $\begin{array}{l}21.2 \% \\
(55)\end{array}$ & $\begin{array}{l}23.1 \% \\
(60)\end{array}$ & $\begin{array}{l}42.6 \% \\
(111)\end{array}$ & $\begin{array}{l}100 \% \\
(260)\end{array}$ \\
\hline $\begin{array}{l}\text { Knowledge of clinical decision } \\
\text { making methods }\end{array}$ & $\begin{array}{l}3.2 \% \\
(8)\end{array}$ & $\begin{array}{l}12.5 \% \\
(32)\end{array}$ & $\begin{array}{l}28.7 \% \\
(74)\end{array}$ & $\begin{array}{l}20.9 \% \\
(54)\end{array}$ & $\begin{array}{l}34.7 \% \\
(92)\end{array}$ & $\begin{array}{l}100 \% \\
(260)\end{array}$ \\
\hline
\end{tabular}




\section{CONCLUSION}

Considering the current status of healthcare, timely access to accurate information is crucial in clinical decision making and providing medical and healthcare services. The results of the present study suggest that the majority of healthcare team members consider the presence of an information seeking expert essential for the healthcare team. Therefore, the medical librarianship curriculum must provide students with specialized education on basic medical terminology and information to increase their general knowledge, thereby facilitating their presence in the healthcare team and providing dynamism and evolution in this discipline. Furthermore, in-service

training programs and supplementary practical courses in hospitals in cooperation with physicians and clinical residents enhance the ability of clinical librarians for understanding the demands and needs of the healthcare team. Coupled with their specialty in searching and retrieving information, the mentioned ability helps establish the status of this major. Purposeful and continuous education to increase the information seeking skills and employment of experienced specialists is the most important factor promoting the status of clinical librarians in the healthcare team. Equipping hospitals and healthcare centers with specialized libraries and specialists; informing hospital staff and healthcare team members, including specialists, regarding the services provided by libraries and medical libraries; and cooperation with clinical libraries are of utmost importance.

\section{REFERENCES}

Abdekhoda, M., \& Dibaj, K. (2011). Medical librarians and new Web technologies: How familiar are we with web facilities and use of library services applications? Journal of Health Informatics in Developing Countries, 5(1).

Aitken, E.M., Powelson, S.E., Reaume, R.D., \& Ghali, W.A. (2011). Involving clinical librarians at the point of care: Results of a controlled intervention. Academic Medicine, 86(12), 15081512.

Ashrafirizi, H.N., Sharzadi, I., \& Soleimani, M. (2016). New services of medical librarians and informatists in the field of health: A narrative review article [In Persian]. Health Information Management, 13(6), 438-444.

Azadehtafreshi, F., Momenzadeh, N., Fayazbakhsh, A., \& Khodaei, A.S. (2010). The role of the librarians in hospitals of Tabriz University of Medical Sciences in evidence-based medicine [In Persian]. Quarterly of Knowledge, 3(11), 33-45.

Brahmi, F.A., \& Kaplan, F.T. (2017). Embedded librarian as research team member. Journal of Hand Surgery, 42(3), 210-212. https://doi.org/10.1016/j.jhsa.2016.12.007

Brettle, A., Maden-Jenkins, M., Anderson, L., McNally, R., Pratchett, T., Tancock, J., ... \& Webb, A. (2010). Evaluating clinical librarian services: A systematic review. Health Libraries Group Health Information and Libraries Journal, 28(1), 3-22.

Brettle, A., Maden, M., \& Payn, C. (2016). The impact of clinical librarian services on patients and health care organisation. Health Information \& Libraries Journal, 33(2), 100-120. https://doi.org/10.1111/hir.12136

Buchalter, A.R., \& Ivey, W.N. (2013). Clinical medical librarians: An annotated bibliography. Washington, D.C.: Federal Research Division, Library of Congress. Retrieved from 
http://www.loc.gov/flicc/publications/FRD/Clinical-Librarian-

Bibliography_April\%202013.pdf

Eresuma, E., \& Lake, E. (2016). How do I find the evidence? Find your librarian-stat!

Orthopaedic Nursing, 35(6), 421-423. https://doi.org/10.1097/NOR.0000000000000299

Esparza, J.M., Shi R., McLarty, J., Comegys, M., \& Banks D.E. (2013). The effect of a clinical medical librarian on in-patient care outcomes. Journal of the Medical Library Association (JMLA), 101(3), 185. https://doi.org /10.3163/1536-5050.101.3.007

Harrison, J., \& Beraquet, V. (2009). Clinical librarians, a new tribe in the UK: Roles and responsibilities. Health Information and Libraries Journal, 27(2), 123-132.

Hashemian, M., Janatikia, M., \& Hashemian, A. (2010). Information seeking skills of the online databases available at the National Library in the Digital Medical University in 89 specialized residents (Research Project no. 289173) [in Persian]. Isfahan, Iran: Health Information Technology Research Center, Isfahan University of Medical Sciences.

Motamedi, F., AleTaha, A., \& Bahaadini, K. (2014). The clinical librarians and information professionals' role in tele-medicine: Assisting the general practitioners working in rural areas of Kerman Province in the treatment process. Journal of Health Management \& Infomatics, 1(2), 31-35.

Roper, T. (2015). The impact of the clinical librarian: A review. Journal of European Association for Health Information and Libraries (EAHIL), 11(4), 19-22.

Asadi-Shali, A., \& Bagheri, M. (2008). Feasibility of clinical library services in hospitals affiliated to Tabriz University of Medical Sciences [In Persian]. Journal of Library, 42(47), $113-138$.

Shokraneh, F. (2015). Clinical librarianship in Iran. Academic medical librarians and libraries: Roles of medical librarians in clinical decision making [In Persian]. Tehran, Iran: National Library and Archives of Islamic Republic of Iran.

Shokraneh, F., Eskrochi, R., Ghafoori, H.B., \& Ghohari M.R. (2010). Run clinical librarian response to questions of clinical emergency medicine faculty and residents, Shohadaye Haftom Tir Hospital, Tehran (Master of Science thesis, in Persian). Tehran, Iran: Iran University of Medical Sciences.

Steele, R., \& Tiffin, P.A. (2014). Personalised evidence for personalised healthcare :Integration of a clinical librarian into mental health services - a feasibility study. Psychiatric Bulletin, 38(1), 29-25.

Valinejadi, A., Pasiar, P., \& Shokraneh, F. (2008). Medical library and information science in the arena of evidence-based medicine [In Persian]. Informology, 5(6), 138-169. 


\section{APPENDIX 1. Questionnaire (English Translation from Persian) \\ Evaluation of Digital Libraries in virtual faculties of Universities in Iran from the viewpoint of virtual students in graduate studies}

Today, libraries are changing from print to electronic and digital. Digital libraries provide information and technology-based services in enabling learners to access relevant information and services at any location, whenever necessary, and enhance lifelong learning. Students of virtual faculties of state universities in the Ministry of Science, Research and Technology, as well as the Ministry of Health and Medical Education, have the most use and communication with digital resources and libraries. This study, based on the current questionnaire, seeks to assess, after more than 10 years of the establishment of virtual colleges, the status and capabilities of current digital libraries from the viewpoint of graduate students in virtual studies, in addition to recognizing the present status and discovering deficiencies to address the decision makers to improve conditions.

1. Does your college have a digital library of digital resources and services?

- Yes, and dependent on the central library and a part of it [ ]

- Yes, independent, and virtual students also use it [ ]

- No []

Other items. Please explain

2. How long have you been using digital library resources?

Less than 6 months [ ] 6 months -1 years [ ] 1-2 years [ ] 2-4 years [ ] over 4 years

3. Identify the different types of information sources you have used and their amount (in each row).

(Circle the number)

$1=$ very low $2=$ low $3=$ average $4=$ high $5=$ very high

\begin{tabular}{|l|l|l|l|l|l|}
\hline Books & 1 & 2 & 3 & 4 & 5 \\
\hline Journals & 1 & 2 & 3 & 4 & 5 \\
\hline Electronic databases related to syllabus & 1 & 2 & 3 & 4 & 5 \\
\hline Newspaper articles & 1 & 2 & 3 & 4 & 5 \\
\hline Conferences' article collections & 1 & 2 & 3 & 4 & 5 \\
\hline Websites & 1 & 2 & 3 & 4 & 5 \\
\hline Research reports & 1 & 2 & 3 & 4 & 5 \\
\hline Theses & 1 & 2 & 3 & 4 & 5 \\
\hline Encyclopedias & 1 & 2 & 3 & 4 & 5 \\
\hline Provided electronic book compact discs by university & 1 & 2 & 3 & 4 & 5 \\
\hline
\end{tabular}


4. How did you access these resources?

- University Library [ ]

- Public Library [ ]

- National Library [ ]

- Library of the work place [ ] Collaborators / Friends / Classmates [ ]

- Specialized Library [ ]

- Submitted Magazine / Newspaper [ ]

- Master or Professor Suggestion [ ]

- Attending conferences [ ]

- Databases []

- University Digital Library [ ]

- Non-University Digital Library [ ]

- Internet [ ]

5. What was your goal when using these resources?

- Promotion of specialized information [ ]

- Doing academic courses [ ]

- Publication of scientific works []

- Preparation of dissertation [ ]

Other Items (Please Name)

6. If you did not use other information resources except those identified as textbooks, please check out.

$1=$ very low $2=$ low $3=$ average $4=$ high $5=$ very high

\begin{tabular}{|l|c|c|c|c|c|}
\hline Not having enough time for research/ extra studying & 1 & 2 & 3 & 4 & 5 \\
\hline Academic materials are sufficient & 1 & 2 & 3 & 4 & 5 \\
\hline $\begin{array}{l}\text { The virtual education center lacks the information } \\
\text { resources I need }\end{array}$ & 1 & 2 & 3 & 4 & 5 \\
\hline I am not allowed to use the university library & 1 & 2 & 3 & 4 & 5 \\
\hline My place of residence is very far away from the library & 1 & 2 & 3 & 4 & 5 \\
\hline $\begin{array}{l}\text { I do not have access to technology to use Internet } \\
\text { services }\end{array}$ & 1 & 2 & 3 & 4 & 5 \\
\hline Access and retrieval costs are very high & 1 & 2 & 3 & 4 & 5 \\
\hline Lack of sufficient training to use enough resources & 1 & 2 & 3 & 4 & 5 \\
\hline
\end{tabular}

Other Items (Please note).

7. Please specify the problems you encountered in accessing resources.

$1=$ very low $2=$ low $3=$ average $4=$ high $5=$ very high 


\begin{tabular}{|l|l|l|l|l|l|}
\hline Lack of time to search for resources & 1 & 2 & 3 & 4 & 5 \\
\hline Lack of knowledge of the correct way to search & 1 & 2 & 3 & 4 & 5 \\
\hline Excessive and irrelevant information on websites & 1 & 2 & 3 & 4 & 5 \\
\hline Failure to find a library that has relevant information & 1 & 2 & 3 & 4 & 5 \\
\hline Lack of equipment and facilities in the library & 1 & 2 & 3 & 4 & 5 \\
\hline The high amount of time spent in obtaining materials & 1 & 2 & 3 & 4 & 5 \\
\hline Limited access / lending of resources from the library & 1 & 2 & 3 & 4 & 5 \\
\hline High costs (photocopy / purchase and ... resources) & 1 & 2 & 3 & 4 & 5 \\
\hline Inappropriate work hours of libraries & 1 & 2 & 3 & 4 & 5 \\
\hline Long distance & 1 & 2 & 3 & 4 & 5 \\
\hline
\end{tabular}

Other Items (Please Note)

Due to the fact that virtual faculties are not currently virtualized in all areas and dimensions, students are forced to attend faculty in order to connect with the university and doing academic activities.

8. In the following, there is a list of topics that are important to support virtual education, please select an order of magnitude from 1 to 5 .

$1=$ very low $2=$ low $3=$ average $4=$ high $5=$ very high

\begin{tabular}{|l|l|l|l|l|l|}
\hline Design a website for the library & 1 & 2 & 3 & 4 & 5 \\
\hline Remote access to full electronic text journals & 1 & 2 & 3 & 4 & 5 \\
\hline A list of websites related to academic majors & 1 & 2 & 3 & 4 & 5 \\
\hline $\begin{array}{l}\text { The existence of a librarian to search for information } \\
\text { resources }\end{array}$ & 1 & 2 & 3 & 4 & 5 \\
\hline A list of libraries that are permitted for use by students & 1 & 2 & 3 & 4 & 5 \\
\hline $\begin{array}{l}\text { Train how to use the Internet to find the information } \\
\text { resources you want }\end{array}$ & 1 & 2 & 3 & 4 & 5 \\
\hline $\begin{array}{l}\text { Better access to university libraries is allowed for university } \\
\text { students }\end{array}$ & 1 & 2 & 3 & 4 & 5 \\
\hline Electronic transmission of ordered articles via fax / e-mail & 1 & 2 & 3 & 4 & 5 \\
\hline A list of books / journals / articles related to each field & 1 & 2 & 3 & 4 & 5 \\
\hline Postal lending service of books or articles & 1 & 2 & 3 & 4 & 5 \\
\hline $\begin{array}{l}\text { Traditional library services for people who do not have } \\
\text { access to the Internet. }\end{array}$ & 1 & 2 & 3 & 4 & 5 \\
\hline Copies of available online books. & 1 & 2 & 3 & 4 & 5 \\
\hline
\end{tabular}




\begin{tabular}{|l|c|c|c|c|c|}
\hline $\begin{array}{l}\text { Providing educational units on how to find and use the } \\
\text { Internet and libraries }\end{array}$ & 1 & 2 & 3 & 4 & 5 \\
\hline Access to the University Library & 1 & 2 & 3 & 4 & 5 \\
\hline Interlibrary Loan Services & 1 & 2 & 3 & 4 & 5 \\
\hline $\begin{array}{l}\text { Telephone reference or e-mail services of online evaluated } \\
\text { resources }\end{array}$ & 1 & 2 & 3 & 4 & 5 \\
\hline Online access to university information databases & 1 & 2 & 3 & 4 & 5 \\
\hline Providing RSS service & 1 & 2 & 3 & 4 & 5 \\
\hline Providing ALERT service. & 1 & 2 & 3 & 4 & 5 \\
\hline
\end{tabular}

9. In addition to accessing electronic resources, do you have issues related to education and research and related resources provided through an electronic portal and in virtual form?

A. Yes. I have all the resources and research resources virtually and I can download them

B. No, I have to be in person to access resources and I have access restrictions

10. Which of the following library services do you have access to virtualistically?

- Virtual Reference Services (WEB2) [ ]

- Database services such as ISI, SCOPUS outside the main portal of the university and accessed simultaneously with the training environment [ ]

- Permission of downloading and saving textbooks [ ]

- Link to other college information resources and collections at the same time [ ]

- Link to other virtual libraries [ ]

- Links to other faculties and virtual courses [ ]

11. Please write your own definition from the digital library?

12. Please provide your comments and suggestions on the library and digital library services in virtual education.

13. What problems do virtual students encounter with digital libraries? 